\title{
Local Government in Inter-Governmental Relations in Nigeria: Effects on Governance and Project Implementation
}

\author{
Enefiok E. Ibok Ph.D, Ekpe A. Ntekim Ph.D \\ ${ }^{I}$ Department of Public Administration Faculty of Social and Management Sciences Akwa Ibom State University \\ Obio Akpa Campus, Oruk Anam Local Government Area, P. M. B. 31167 Akwa Ibom State \\ ${ }^{2}$ (Associates Professor) Department of Public Administration Faculty of Social and Management Sciences \\ Akwa Ibom State University P. M. B. 31167 Obio Akpa Campus, Oruk Anam Local Government Area, Akwa \\ Ibom State, Nigeria
}

\begin{abstract}
Inter-governmental relations in Nigerian federation entails formal allocation of powers both vertical and horizontally among various levels of government. In this relationship local government is seen as a thirdtier or level of government with power to transform their areas of jurisdiction through good governance. This study was to assess the effect of such relationship on the governance and project implementation by local government. The study adopted a historical and descriptive approach in data collection. The study therefore, revealed that right from 1954 - 1979, Local governments have been subjected to all sort of control by other tiers of government, namely federal and state governments. The study further revealed that following 1976 local government reforms, it was believed that, the situation would improve, but instead, the status quo still remained. This lopsided relation has impacted negatively on good governance, and by extension inability to implement live touching projects. Based on this, the study recommended that local government should be allowed to function as governments with minimal control from the state governments. Also, the on-going National Conference should alter section 7(1) of the present 1999 and 2011 amended constitutions for local government to be constitutionally created and not state.
\end{abstract}

Keywords: Local government, inter-governmental relations, governance, project implementation

\section{Introduction}

It is a well known fact by practitioners and scholars that local government is a viable tool for rural transformation and delivery of social services to the people. Whether unitary or federal political system; the strategic importance of local government to the developmental process is not in doubt. However, this is contingent on the relationship that exists among levels or tiers of government. In Nigeria federation, local government by constitutional provision stands as a distinct level vis-a-vis federal and state governments.

The concept of intergovernmental relations took the centre stage at a period when they were numerous and complex problems facing three levels of government. The concept has its beginning in Nigeria around 1950 s with the establishment of advisory body on intergovernmental relations. This was necessary because of numerous and complex problems confronting three levels of government in our heterogeneous society. This interrelationship becomes necessary for the achievement of national integration for a harmonious coexistence of the parts, as well as the whole for good governance and meaning development. The six patterns of relationships in Nigeria intergovernmental relations are;

(i) federal-state relations

(ii) federal-state-local relations

(iii) federal-local relations

(iv) inter-state relations

(v) state-local relations, and

(vi) inter-local relations

Our intention is to examine the place of local government in Nigeria's inter-governmental relations, and its effects on good governance and project implementation.

\section{Study Location}

Nigeria is situated on the gulf of Guinea in West Africa between latitudes $4^{\circ}$ and $14^{\circ}$ north and longitudes $3^{\circ}$ and $14^{\circ}$ east. Its neighbours are Benin, Niger, Cameroon and Chad Republics. There are 36 states in Nigeria, including Abuja, the federal capital territory. The country operates federal system of government made up of three levels of government namely, Federal, State and Local government. Before its independence on October 1, 1960, the territory now known as Nigeria was under the British colonial rule. Today, the country has grown tremendously to a population size of about $152,217,341$ people. 
Nigeria is a heterogeneous society with multiple cultural, ethnic and lingual diversities. A significant size of the population (about $70 \%$ ) lives in the rural areas where local government as a third levels of government in intergovernmental relations is primarily responsible for the provision of physical, social and public services to the people (Ekpe, Daniel and Ekpe, 213).

\section{Intergovernmental Relations: Conceptual Clarification}

The concept of Intergovernmental Relations (IGR) refers to an important body of activities, or interactions occurring between governmental units of all types and levels within a federal system. It is the manner in which the units or the agents of the state associate with each other, whether civilian or otherwise especially under the federal arrangement. Explaining further, Anderson (1979) observes that IGR "is a term intended to designate an important body of activities or interactions occurring among governmental units of all types of levels within the federal system". He noted that, though complexity IGR are common features of all federal political systems, they are not necessarily limited to federal political systems. To be sure, he says, complexity and problems of IGR do exist, to a reasonable extent, in all unitary political systems. However, it is pertinent to underscore the fact that the units and levels of government that engage in IGR are more prevalent in federal systems, than in unitary system of government.

Gboyega in Ekpe (2002) notes that even though the nature of relationship existing among Federal, States and Local Governments from the constitutional point of view tends to be fiscal, a lot of mechanisms or agencies exist among them that tend to link or heighten the relationship of the three levels of government in Nigeria. surely, there exist a complex web of interactions bordering on participatory and joint management in the areas of funding of primary education, poverty alleviation programme, training of local government career and elected officers among others.

In a corroborative view, Gboyega (1989) speaks on the present mechanisms of fiscal transfers among the three levels of government. He says that the mechanism of the State Joint Local Government Account Committee is lopsided, and that it is more often being manipulated by most officials in favour of the State Government, (Ekpe, 2002).

Adewale (1995) sees IGR as embracing three perspectives: political, social and economic efforts of government and various bodies in the state directed towards the enhancement of the goals and objectives. To him, IGR does not refer to aspect of transferring or distributing grants or funds nor is it only an interjurisdictional conflicts resolving unit, but as a complex network or transactions among constituents and various bodies in the State.

Bello-Imman (1990) holds a broader view of the concept of IGR. His point of emphasis is on the three types of IGR practised the world over. These according to him are partnership model, principal/agent model and functional dualism model. He maintained that Nigeria's IGR historically exhibits the characteristic of principal/agent model during the colonial and first republic eras. This implies that the relationship between the local government and other higher levels, federal and state is not based upon co-operatives situation, rather a relationship where the local government takes directive and commands from the higher authority or body.

Supporting the above view, Ayoade (1992) sees the state-local government relationship as that of principal and agent, as the local government is a creation of the state government. He observed further that, whereas national state relations are regulated by the constitution such that both levels of government are coequal to their respective spheres of co-operation, the state-local government relationship is that of a principal and agent. From this, one can deduce that, the local government only exercise such powers as permitted by the state government. On the other hand, within this frame of mind, IGR at state - local and inter-local levels are a function of the diversity of the state. He notes that regardless of the powers given to the local government, IGR will be a function of whether the same or different political parties control the state and the local governments.

He (Ayoade) added, in a situation where the same political party is in power at the state and the local government levels, IGR tends to be positive, because the relationship between the two levels of government is symmetrical. But where different political parties control state and local government, the relationship is asymmetrical and IGR tends to be negative.

At this point, our focus is shifted from concept clarification of IGR which centres on formal constitutional division of powers, to examination of models or typology of IGR based on the authority structure which is dependent on the totality of executive and financial capacities of each level of government. An in-dept examination of these models will help us x-ray Nigerian situation as it affect local governance and project implementation right from 1954 when Nigeria started experimenting with federalism.

\section{Typology of Intergovernmental Relations}

Many scholars have devised models to guide in understanding inter-governmental relations. Perhaps, the best and most important of these models is the three-fold typology formulated by Deil S. Wright an 
American. His conceptual models are: Separate IGR model, overlapping/bargaining IGR model and inclusive IGR models, (Wright, 1978).

\section{Separated IGR Model}

In this model, the state governments are independent (within the constitutional limitations) of the federal government, while the local governments are subordinated to the state (regions/provinces). This model was experimented in Nigeria between $1954-1966$. The regional governments during this era were very powerful, as they controlled substantial portions of their natural resources, wealth etc.

The relationship that exists between the local government and the regional governments is a superordinate/subordinate relationship. Nwosu (1989) likened the relationship to a horse (local Government) and a rider (regional government). The regional government created, controlled and abolished local government as they deemed necessary. The point is that the Federal government had little or no direct dealing with the local government. Local Government existed at the mercy of regional government. This really affected good governance at local government level and their functions in terms of project implementation.

Suffice to say that with the incursion of the military in 1966, witnessed a shift in the power base and concomitant increase of federal government power over other tiers of government. This means that there was an enhanced dependency of the regions and local governments on the federal government, even though, the local government were still tied to the apron or umbilical cord of the regional governments.

\section{Inclusive IGR Model}

Here the state governments as well as local governments are mere appendages to the federal government. Federal - state relations were characterised not only by increasing dependence of the states/regions on the centre, but also by the ubiquity of the federal government in areas considered an exclusive preserve of the state/regional government, (Akinsanya, 1989). This model characterised the era of military rule in Nigeria (1975 - 1988) when the Republican legislative, executive and financial functions were vested on the federal government. This supremacy of federal governments over other tiers of government were attributed to a number of factors such as: the nature of military establishment; the creation of more states; the increase federal revenue due to oil boom; the emergence of a new breed of Nigerians strongly committed to a strong national government; and the existence of intergovernmental institutions (Davies, 1992).

\section{Overlapping/Bargaining IGR Model}

Here, power is shared among the three levels of government, so there is some measure of autonomy enjoyed by each level of government, but not to the extent that this leaves each level of government capable of independent action in each sphere. It is interesting to note that Federal-State-Local government relation during the Nigeria second republic till date (1979-present) approximates the overlapping authority model. In this model, we observed that virtually all tiers of government are involved in all governmental functions.

1.

The three patterns/typologies of IGR in Nigeria from 1954 till date is presented graphically. See figure

\section{Patterns/Typologies Of Igr In Nigeria}

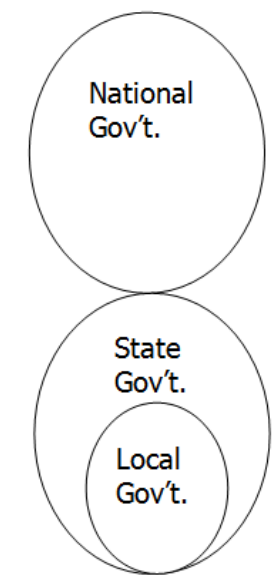

Separated/coordinate Pattern 1954 - 1966

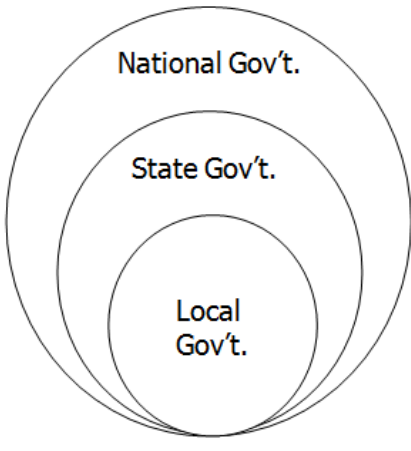

Inclusive/Dependent

Pattern 1966 - 1979

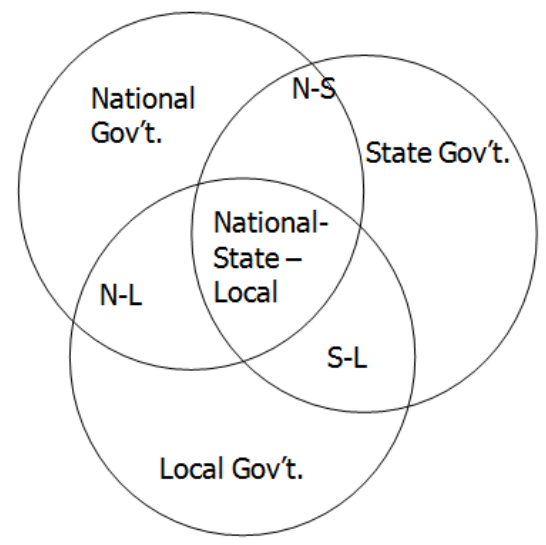

Overlapping/Bargaining

Pattern 1979 - Present

Source: Understanding Intergovernmental Relations, North Oscillate. Mass Duxbury press (1978). 
However, it is pertinent to say that following 1976 local government reforms and as provided for in the constitution of Nigeria $(1979,1999$, and 2011 as amended) attempts have been made to delineate a three-tiered federal structure in which each tier possesses a considerable degree of independence - jurisdictionally, functionally and financially even if some forces appear to tilt the balance of power in favour of the centre and rarely in favour of states' and local government. Akinsanya, (1995) observed:

The relationship between the state and local governments is a superordinate - subordinate relationship, because the state governments have powers of control and supervision over local governments... what seems to have compounded the dilemma of local governments as effective third-tier system of government is the power exercised by the new local government areas and removal of council chairman from office. If state governments can exercise power of control and supervision over local governments; if disbursements of federal statutory allocations to local governments can be suspended or withheld to ensure compliance with state policy and directives; indeed, if council chairmen can be removed from office by a federal fiat, and if new local government areas can be created at the pleasure of federal and state governments... we cannot, strictly speaking, continue to talk of local governments as the third-tier system of government. Additionally, if state governments can conduct inquiries into the activities of local government councils, one begins to question the propriety of disciplinary powers being exercised by local government council over council chairman, (Akinsanya, 1995: 43).

As noted above, ordinarily, one would have expected a change in the relationship in 1999 and 2011 as amended constitutions, but, instead, the situation is appalling. An examination of some contemporary issues or forces which tilt balance of power in favour of states vis-a-vis local government in particular need be highlighted and its effect on good governance and project implementation by local governments.

\section{Local government in intergovernmental relations effects on governance and project implementation}

This will be analyse based on the following headings; functional competency, fiscal relations, constitutional provision, election of political leadership and administrative control.

\section{Functional Competence}

A closer investigation shows that local government activity is still confined to the same narrow functional competence as before the reform of 1976. Participation in some of the more technical and strategic services is rare, despite the involvement expected by the 1976 reform guidelines. Hence, local government participation in economic planning is minimal and their activities are generally poorly linked to the development plan programmes. For instance, local governments are not responsible for managing the Universal Primary Education programme (UPE) eventhough they make a substantial contribution to it. Also, they are left out of the housing programme, agricultural revolution, water and electricity programmes in their domain. To administer these programmes, the federal and state governments have created special agencies such as River Basin Development Authority (RBDA), State Universal Basic Education Board (SUBEB), Cross River Agricultural Development Projects (CRADP), Akwa Ibom Agricultural Development Project (AKADEP), Akwa Ibom Rural Water Projects (AK-RUWATSON) and Akwa Ibom Investment Company (APIICO) etc, (Ibok and Tom, 2010).

\section{Fiscal Relations}

The stranglehold which state governments continued to exercise over local government through the Joint Account Committee enables the states to dictate the formulae governing allocations of such monies among local governments. Also the role granted state governments as umpires for local government in the matter of statutory allocation saw states governments making deductions and in most instances withholding such allocations to local government at wills. For example, the purchase of patrol vans for the police, thirty one tractors for the 31 local governments in Akwa Ibom State being directed and handled by the state government without any input or permission from the local government. Also, the purchased of vehicles for the monitoring of primary schools in Yobe state by the state government and the cost of the vehicles charged to local government account singlehandedly. Another instance is collusion of Federal Ministry of Finance with the Association of Local Government of Nigeria (ALCON) to purchase 1,000 brand new Prado Patrol Jeeps for the Nigerian Police Force and the cost unilaterally deducted at source from local government accounts, (Eminue, 2006).

To worsen the matter, most state governments have outrightly failed to fulfil their statutory obligation of giving to local governments $10 \%$ of their internally generated revenue. This is provided for the Revenue Federation Account Act of 1982. As a result local government experienced huge short falls in their revenue which made planning for development, and the provision of essential services difficult, if not impossible. 


\section{Constitutional Provision}

The ambiguity of section 7(1) of the 1999 and 2011 as amended constitution of Nigeria vests in states the supervisory powers over local governments. One of such subservience pertains to the legislation which empowers the governor to dissolve crisis ridden local council and also remove erring chairman/councillors if he is not satisfied with how such council is managed. In the event of such dissolution, he can appoint an administrator or a caretaker committee to pilot the affairs of such council. This provision has been grossly abused by some state governors. For example, the removal of Ikot Abasi local government chairman by the state government in Akwa Ibom State and dissolution of Akpabuyo local government council in Cross River State for trivialities has bastardised this constitutional provision, thereby rendering local government impotent in its constitutional function of project implementation and service delivery to the local communities (Ibok and Tom, 2010).

Another unpalatable example is the suspension of a local government chairman in Ebonyi State for disobeying a House of Assembly Resolution on Joint State/Council Accounts. In Kaduna State, the State Governor sacked the Chairman of Jema'a Local Government for alleged financial irregularities, etc. (Eminue, 2006).

\section{Political Leadership/Administrative Control}

State - local relations as exemplified by 'a master - servant' relationship is obvious in areas such as absence of local government election in some States; political leadership at the local level consists of hand picked favourites of the governors or the ruling party. Hence, council's management tends to be loyal to their masters than the people. Also, the establishment and control mechanism by the state government to oversee local government such as, the Ministry of Local Government, Local Government Service Commission and the State Economic Planning Board. These bodies are state institutions created to control local governments, (Olowu, 2006). As if the problems facing local governments as an effective third-tier system of government are not daunting, cases of profligacy and allegations of corruption involving council chairmen cannot but invite the investigatory powers of state governments which further reinforce superordinate-subordinate relationship between state and local government.

The above scenario shows that local government have been relegated to the background, and subjected to the cavalier and whimsical tinkering of the state government, (Akande, 1982). This lopsided relationship has actually affected good governance as well as project implementation by local governments throughout the country. No wonder there has been a call from different quarters for the abrogation of this level of government in Nigeria.

\section{Conclusion}

In this study, we have ex-rayed the place of local government in Nigeria's inter-governmental relations. One outstanding issue in this relationship is that, the Nigerian constitution confers on the state, the legal existence and as a result, the local governments are state creation through laws passed by the various Houses of Assembly within the context of 1999 and 2011 Nigerian constitution as amended, section 7(1) which provides that "the system of local government by democratically elected local government council is under this constitution guaranteed, and accordingly, the government of every state shall ensure their existence, under the law which provide for the establishment, structure, composition, finance and functions of such council".

The above constitutional provision is appalling and awful because following 1976 local government reforms in Nigeria, it was believed that, local government would be repositioned as a distinct level of government with full governmental powers and authority, but instead the constitutional provisions continued to subject local government to a subservient, slave and subordinate position tied to the apron of the higher level of government especially the state government. This subjugated position in all ramifications has affected good governance and its functional competence, especially in the area of project implementation. This is so because there are no meaningful projects embarked upon by this level of government across the country because of their position as a 'Weeping Child'.

\section{Recommendations}

Nigeria is a unique federal state, where local governments are regarded as a separate arm of government, a third tier system of government. For local governments to remain effective third-tier system of government the following are recommended:

1. That local governments should be allowed to function as a government with minimal control from the state governments.

2. That the ongoing national conferences should alter section 7(1) of 1999 and 2011 amended constitution so that local government be constitutionally created and not states. 
3. The federal allocation meant for local governments should be sent directly to local government and, not through State- Local Government Joint Account.

4. That both federal and state governments should stop unilateral/illegal deductions from local government share of revenue rather; such deduction must be discuss and agreed upon by all the parties.

5. That, the account/records of the councils should be audited from time to time by the higher level of government, notably state government to ensure enthronement of financial discipline in running council's affairs.

6. To ensure effective governance and project implementation, political heads of the local government council should be elected by the people who will in turn be accountable to the people.

7. State and local government relationship should anchor on the need to promote cooperation and partnership between them, and not on confrontation and competition.

8. Tax shares or grants to local governments in Nigeria should be tied to priority projects or programmes to forestall a situation where available funds of councils are wasted on administrative/overhead costs of councils.

\section{References}

[1]. Adewale, I. A. (1995). Review of Nigeria's intergovernmental relations: A publication in New trend in Nigeria Local Government edited by A. N. Awotokun pp. $52-59$.

[2]. Akande, J. A. (1982). Introduction to the constitution of the federal republic of Nigeria 1979. London: Sweet and Maxwell.

[3]. Akindele, S. T. (2004). "Political mobilization for rural development and a stable Nigerian democratic republic: An indepth examination of the Role of local government," in Journal of Human Ecol. 16 (2): 99 - 112

[4]. Akinsanya, A. (1989). "Federal - state relations in Nigeria since independence", in Quarterly Journal of Administration, April/July pp. 109- 127.

[5]. Akinsanya, A. (1995). "Local government in inter-governmental relations in Nigeria". January, 98 Pakistan Horizon p. 43.

[6]. Anderson, W. (1979). Intergovernmental relations in Review. Minneapolis: University of Minnesota.

[7]. Ayoade, J. A. A. (1992). "Policy conflicts and distortion under the federal system" Abuja: Centre for Democratic Studies.

[8]. Bello, Imman I. B. (1990). "Structured Evolution of local Government in Nigeria: A seminar paper on professionalism in the local government service, Kano.

[9]. Davis, A. E. (192). "The place of local government in intergovernmental relations. Illorin: University of Illorin.

[10]. Eminue, O. (2006). "Federal - state-local relations: Contending issues in Nigerian Federalism under Olusegun Obasanjo. In: Ekpe, A. the substance of Local government administration in Nigeria (Theory and Practice) Lagos: Asbot, p. 191.

[11]. Ekpe, A. N., Daniel, E. E. Martha, A. E. (2013). Analysis of performance appraisal system of the Nigerian Public Sector organizations. Journal of Humanities and Social Sciences, vol. 18, issues 3, pp. $49-58$, Retrieved from www.iosrjournals.org.

[12]. Gboyega, A. in Ekpe A. N. (2002). Intergovernmental Relations in Nigeria: Concepts, problems and Prospects. Uyo: Jim-print communications Ltd., p. 4.

[13]. Ibok, E. Tom, E. (2010). Introduction to Local government administration in Nigeria: Contemporary issues. Uyo: Edimson.

[14]. Nwosu, A. (2000). Policy implementation and agricultural transformation in Nigeria: proceedings of a national conference in honour of Professor Martin O. Ijere. Owerri: Novelty Industrial Enterprises.

[15]. Olowu, D. (2006). "Local governments and intergovernmental relations in Nigeria" in Ekpe, A: The Substance of local government administration in Nigeria. (Theory and Practiced), Lagos: Asbot, p. 151.

[16]. Wright, D. S. (1978). Understanding inter-governmental relations. North Scituate Mass: Duxbury Press. 